\title{
Role of Support Oxygen Vacancies in the Gas Phase Hydrogenation of Furfural over Gold
}

\author{
Maoshuai Li $^{1} \cdot$ Laura Collado $^{1} \cdot$ Fernando Cárdenas-Lizana $^{1} \cdot$ Mark A. Keane $^{1}$
}

Received: 17 August 2017 / Accepted: 9 October 2017 / Published online: 23 October 2017

(c) The Author(s) 2017. This article is an open access publication

\begin{abstract}
We have examined the role of support oxygen vacancies in the gas phase hydrogenation of furfural over $\mathrm{Au} / \mathrm{TiO}_{2}$ and $\mathrm{Au} / \mathrm{CeO}_{2}$ prepared by deposition-precipitation. Both catalysts exhibited a similar Au particle size distribution (1-6 nm) and mean (2.8-3.2 nm). Excess $\mathrm{H}_{2}$ consumption during TPR is indicative of partial support reduction, which was confirmed by $\mathrm{O}_{2}$ titration. Gold on $\mathrm{CeO}_{2}$ with a higher redox potential exhibited a greater oxygen vacancy density. A lower furfural turnover frequency (TOF) was recorded over $\mathrm{Au} / \mathrm{CeO}_{2}$ than $\mathrm{Au} / \mathrm{TiO}_{2}$ and is linked to suppressed $\mathrm{H}_{2}$ chemisorption capacity and strong $-\mathrm{C}=\mathrm{O}$ interaction at oxygen vacancies that inhibited activity. Gold on non-reducible $\mathrm{Al}_{2} \mathrm{O}_{3}$ as benchmark exhibited greater $\mathrm{H}_{2}$ uptake and delivered the highest furfural TOF. Full selectivity to the target furfuryl alcohol was achieved over $\mathrm{Au} /$ $\mathrm{TiO}_{2}$ and $\mathrm{Au} / \mathrm{Al}_{2} \mathrm{O}_{3}$ at $413 \mathrm{~K}$ and over $\mathrm{Au} / \mathrm{CeO}_{2}$ at $473 \mathrm{~K}$ with hydrogenolysis to 2-methylfuran at higher reaction temperature $(523 \mathrm{~K})$. A surface reaction mechanism is proposed to account for the activity/selectivity response.
\end{abstract}

\section{Graphical Abstract}

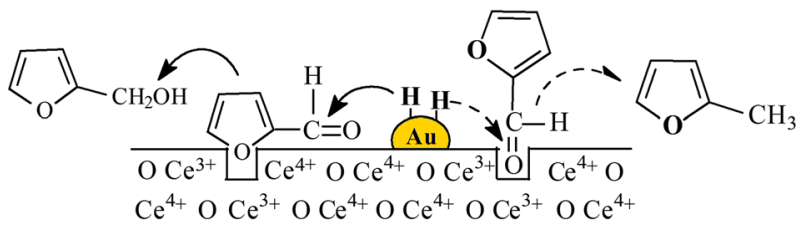

Mark A. Keane

M.A.Keane@hw.ac.uk

1 Chemical Engineering, School of Engineering and Physical Sciences, Heriot-Watt University, Edinburgh EH14 4AS, Scotland, UK
Keywords Selective hydrogenation · Furfural · Furfuryl alcohol · Oxygen vacancies $\cdot$ Supported Au

\section{Introduction}

Oxygen vacancies in metal oxides (e.g. titanium, cerium, iron and vanadium oxides) are defects generated by the loss of lattice oxygen as a result of high temperature ( $\geq 673 \mathrm{~K})$ annealing in ultra-high vacuum [1], chemical reduction (by $\mathrm{H}_{2}$ or $\mathrm{CO}$ ) [2] and/or electron irradiation [3]. The formation and properties of these vacancies have been the subject of theoretical (DFT) and experimental (UPS, XPS, EELS, IR, EPR, STM) work [4-6]. Contributions due to oxygen vacancies have been established in catalytic water-gas shift [7], steam reforming of oxygenates [8], CO oxidation [9] and hydrodeoxygenation [10]. Moreover, the presence of these defects can modify the electronic characteristics (via electron transfer) [11], particle size (by stabilisation at vacancy sites) [12] and chemical properties (metal-support interaction) [13] of the supported metal phase (Pt [7], Ag [11], $\mathrm{Au}$ [13] and Pd [14]), which impact on reactant adsorption/ activation. Hydrogenation is a key process in the food, petrochemical, pharmaceutical and agrochemical sectors [15]. The effect of surface oxygen vacancies in catalytic hydrogenation is still a subject of debate. Enhanced activity and ( $-\mathrm{C}=\mathrm{O}$ reduction) selectivity reported for $\mathrm{Pt} / \mathrm{CeO}_{2}[16]$ and $\mathrm{Au} / \mathrm{Fe}_{2} \mathrm{O}_{3}$ [17] in the hydrogenation of crotonaldehyde and benzalacetone was attributed to facilitated activation of the carbonyl function at oxygen vacancies and/or electronrich metal nano-particles. On the other hand, a (threefold) decrease in crotonaldehyde hydrogenation activity was observed following incorporation of $\mathrm{CeO}_{2}$ (by impregnation with $\left.\mathrm{Ce}\left(\mathrm{NO}_{3}\right)_{3}\right)$ on $\mathrm{Ru} / \mathrm{Al}_{2} \mathrm{O}_{3}$ and ascribed to strong $-\mathrm{C}=\mathrm{O}$ interaction with oxygen deficient sites [18]. Tian 
et al. [19] studying the hydrogenation of cinnamaldehyde over $\mathrm{Au} / \mathrm{CeO}_{2}$ suggested a preferential $-\mathrm{C}=\mathrm{C}$ - adsorption on $\mathrm{Au}^{\delta+}$ (resulting from electron transfer to support defects) to explain lower selectivity in terms of $-\mathrm{C}=\mathrm{O}$ reduction. In the hydrogenation of $p$-chloronitrobenzene, unwanted hydrodechlorination was reported for $\mathrm{Au} / \mathrm{Ce}_{0.62} \mathrm{Zr}_{0.38} \mathrm{O}_{2}$ and ascribed to $-\mathrm{C}-\mathrm{Cl}$ scission at vacancy sites [20]. In this study, we consider the role of oxygen vacancies (on reducible $\mathrm{TiO}_{2}$ and $\mathrm{CeO}_{2}$ ) in determining the catalytic performance of supported $\mathrm{Au}$ in gas phase hydrogenation of $-\mathrm{C}=\mathrm{O}$ using furfural as model reactant. Gold on non-reducible alumina serves as a benchmark catalyst.

\section{Experimental}

\subsection{Materials and Catalyst Preparation}

Commercial $\mathrm{TiO}_{2}$ (P25, Degussa) and $\mathrm{CeO}_{2}$ (SigmaAldrich) were used as received. The supported Au catalysts were prepared by deposition-precipitation using urea (100-fold excess, Riedel-de Haën, 99\%) with $\mathrm{HAuCl}_{4}$ $\left(1.5 \times 10^{-3}-3.0 \times 10^{-3} \mathrm{M}, 400 \mathrm{~cm}^{3}\right.$, Sigma-Aldrich, $\left.99 \%\right)$. A suspension containing the oxide carrier $(10 \mathrm{~g})$ was heated to $353 \mathrm{~K}\left(2 \mathrm{~K} \mathrm{~min}^{-1}\right)$ where the $\mathrm{pH}$ progressively increased to $c a$. 7 after $3-4 \mathrm{~h}$ as a result of urea decomposition [21]. The solid obtained was separated by filtration, washed with distilled water until chlorine free (from $\mathrm{AgNO}_{3}$ test) and dried in $\mathrm{He}\left(45 \mathrm{~cm}^{3} \mathrm{~min}^{-1}\right)$ at $373 \mathrm{~K}\left(2 \mathrm{~K} \mathrm{~min}^{-1}\right)$ for $5 \mathrm{~h}$. The resultant sample was sieved (ATM fine test sieves) to mean particle diameter $=75 \mu \mathrm{m}$, activated at $2 \mathrm{~K} \mathrm{~min}^{-1}$ to $523 \mathrm{~K}$ in $60 \mathrm{~cm}^{3} \mathrm{~min}^{-1} \mathrm{H}_{2}$, cooled to ambient temperature and passivated in $1 \% \mathrm{v} / \mathrm{v} \mathrm{O}_{2} / \mathrm{He}$ for $1 \mathrm{~h}$ for ex situ characterisation. Synthesis and activation of the benchmark $\mathrm{Au} / \mathrm{Al}_{2} \mathrm{O}_{3}$ catalyst is described in detail elsewhere [22].

\subsection{Catalyst Characterisation}

The Au content was measured by atomic absorption spectroscopy (Shimadzu AA-6650 spectrometer with an airacetylene flame) from the diluted extract in aqua regia $\left(25 \% \mathrm{v} / \mathrm{v} \mathrm{HNO}_{3} / \mathrm{HCl}\right)$. Temperature programmed reduction (TPR), $\mathrm{H}_{2}$ and $\mathrm{O}_{2}$ chemisorption measurements were conducted on the CHEM-BET 3000 (Quantachrome Instrument) unit with data acquisition/manipulation using the TPR Win ${ }^{\mathrm{TM}}$ software. Samples were loaded into a U-shaped Pyrex glass cell (3.76 $\mathrm{mm}$ i.d.) and heated in $17 \mathrm{~cm}^{3} \mathrm{~min}^{-1}$ (Brooks mass flow controlled) $5 \% \mathrm{v} / \mathrm{v} \mathrm{H}_{2} / \mathrm{N}_{2}$ to $523 \mathrm{~K}$ at $2 \mathrm{~K} \mathrm{~min}^{-1}$. The effluent gas passed through a liquid $\mathrm{N}_{2}$ trap and $\mathrm{H}_{2}$ consumption was monitored by a thermal conductivity detector (TCD). The activated samples were swept with $65 \mathrm{~cm}^{3} \min ^{-1} \mathrm{~N}_{2}$ for $1.5 \mathrm{~h}$, cooled to $413 \mathrm{~K}$ and subjected to $\mathrm{H}_{2}$ chemisorption by pulse $(10 \mu \mathrm{l})$ titration. In blank tests, there was no measurable $\mathrm{H}_{2}$ uptake on the oxide supports alone. Oxygen chemisorption post-TPR was employed to determine the extent of support reduction [23], where the samples were reduced as described above, swept with $65 \mathrm{~cm}^{3} \mathrm{~min}^{-1} \mathrm{He}$ for $1.5 \mathrm{~h}$, cooled to $413 \mathrm{~K}$ with pulse $(50 \mu \mathrm{l}) \mathrm{O}_{2}$ titration. It has been demonstrated previously that $\mathrm{Au}$ contribution to total $\mathrm{O}_{2}$ adsorbed is negligible [24]. Nitrogen physisorption was performed using the commercial Micromeritics Gemini 2390p system. Samples were outgassed at $423 \mathrm{~K}$ for $1 \mathrm{~h}$ prior to analysis. Total specific surface area (SSA) was calculated using the standard single point BET method. X-ray diffractograms (XRD) were recorded on a Bruker/Siemens D500 incident X-ray diffractometer using $\mathrm{Cu} \mathrm{K} \alpha$ radiation, scanning at $0.02^{\circ}$ per step over the range $20^{\circ} \leq 2 \theta \leq 80^{\circ}$. The diffractograms were identified against the JCPDS-ICDD reference standards, i.e. $\mathrm{Au}$ (04-0784), anatase- $\mathrm{TiO}_{2}$ (21-1272), rutile- $\mathrm{TiO}_{2}$ (211276), $\mathrm{CeO}_{2}$ (43-1002) and $\mathrm{Ce}_{2} \mathrm{O}_{3}$ (23-1048). Gold particle morphology was examined by scanning transmission electron microscopy (STEM, JEOL 2200FS field emission gunequipped unit), employing Gatan Digital Micrograph 1.82 for data acquisition/manipulation. Samples for analysis were prepared by dispersion in acetone and deposited on a holey carbon/Cu grid (300 Mesh). The surface area weighted mean Au particle size (d) was based on a count of at least 300 particles, according to

$$
d=\frac{\sum_{i} n_{i} d_{i}^{3}}{\sum_{i} n_{i} d_{i}^{2}}
$$

where $n_{i}$ is the number of particles of diameter $d_{i}$.

\subsection{Catalyst Testing}

Hydrogenation of furfural (Sigma-Aldrich, 99\%) was carried out at atmospheric pressure and $413-523 \mathrm{~K}$ in situ after activation in a continuous flow fixed bed tubular reactor $(15 \mathrm{~mm}$ i.d.). Reactions were conducted under operating conditions that ensured negligible mass/heat transport limitations. A layer of borosilicate glass beads served as preheating zone, ensuring that the furfural reactant was vaporised and reached reaction temperature before contacting the catalyst. Isothermal conditions $( \pm 1 \mathrm{~K})$ were ensured by diluting the catalyst bed with ground glass $(75 \mu \mathrm{m})$, which was mixed thoroughly with catalyst before loading into the reactor. Reaction temperature was continuously monitored by a thermocouple inserted in a thermowell within the catalyst bed. Furfural was delivered as $n$-butanolic (Sigma-Aldrich, $>99 \%$ ) solutions to the reactor via a glass/Teflon air-tight syringe and Teflon line using a microprocessor controlled infusion pump (Model $100 \mathrm{kd}$ Scientific) at a fixed calibrated flow 
rate. A co-current flow of furfural and $\mathrm{H}_{2}$ was adjusted to $G H S V=1 \times 10^{4} \mathrm{~h}^{-1}$. The molar Au to inlet reactant molar feed rate $(n / F)$ spanned the range $4 \times 10^{-3}-30 \times 10^{-3} \mathrm{~h}$. Passage of furfural in a stream of $\mathrm{H}_{2}$ through the empty reactor or over support alone did not result in any detectable conversion. The reactor effluent was condensed in a liquid $\mathrm{N}_{2}$ trap for subsequent analysis using a Perkin-Elmer Auto System XL gas chromatograph equipped with a programmed split/ splitless injector and a flame ionisation detector, employing a DB-1 ( $50 \mathrm{~m} \times 0.33 \mathrm{~mm}$ i.d., $0.20 \mu \mathrm{m}$ film thickness) capillary column (J\&W Scientific). Data acquisition and manipulation were performed using the TurboChrom Workstation Version 6.3.2 (for Windows) chromatography data system. Furfuryl alcohol and 2-methylfuran were used as supplied (Sigma-Aldrich, 99\%) for product identification/analysis. All gases $\left(\mathrm{O}_{2}, \mathrm{H}_{2}, \mathrm{~N}_{2}\right.$ and $\left.\mathrm{He}\right)$ were of high purity (BOC, $>99.98 \%$ ). Furfural fractional conversion $(X)$ is defined by

$X=\frac{[\text { furfural }] \text { in }-[\text { furfural }] \text { out }}{[\text { furfural }] \text { in }}$

and selectivity $(S)$ to product $(\mathrm{j})$ is given by

$S_{\mathrm{j}}(\%)=\frac{[\text { product }] \mathrm{j}, \text { out }}{[\text { furfural }] \text { in }-[\text { furfural }] \text { out }} \times 100$

where the subscripts "in" and "out" refer to the inlet and outlet gas streams. Turnover frequency (TOF, rate per active site) was calculated using Au dispersion measurements from STEM as described elsewhere [25]. Repeated reactions with different samples from the same batch of catalyst delivered raw data reproducibility and carbon mass balances that were within $\pm 5 \%$.

\section{Results and Discussion}

\subsection{Catalyst Characterisation}

The physicochemical characteristics of $\mathrm{Au} / \mathrm{TiO}_{2}$ and $\mathrm{Au} /$ $\mathrm{CeO}_{2}$ are given in Table 1; the values for $\mathrm{Au} / \mathrm{Al}_{2} \mathrm{O}_{3}$ are taken from a prior publication [22]. The samples contained a similar Au loading $(0.6-0.8 \mathrm{~mol} \%)$ where the SSA match values reported for $\mathrm{TiO}_{2}\left(50 \mathrm{~m}^{2} \mathrm{~g}^{-1}\right)$ [26] and $\mathrm{CeO}_{2}$ (36-67 $\left.\mathrm{m}^{2} \mathrm{~g}^{-1}\right)$ [11] supported group IB metal catalysts. XRD analysis (Fig. 1) of $\mathrm{Au} / \mathrm{TiO}_{2}$ (I) revealed a mixture of tetragonal anatase $\left[2 \theta=25.3^{\circ}, 37.8^{\circ}, 48.1^{\circ}\right.$ and $62.8^{\circ}$, (III)] and rutile $\left[2 \theta=27.4^{\circ}, 36.1^{\circ}, 41.2^{\circ}, 54.3^{\circ}, 56.6^{\circ}, 69.0^{\circ}\right.$ and $69.8^{\circ}$, (IV)] phases with an anatase : rutile ratio $(5: 1)$ consistent with Degussa P25 [27]. The XRD pattern of $\mathrm{Au} / \mathrm{CeO}_{2}$ (II) presents principal peaks (at $2 \theta=28.6^{\circ}, 33.1^{\circ}, 47.5^{\circ}$, $56.4^{\circ}$ and $59.1^{\circ}$ ) characteristic of $\mathrm{CeO}_{2}(\mathrm{~V})$. In both cases, there were no diffraction peaks due to $\mathrm{Au}$ (principal peak $2 \theta$ $=38.1^{\circ}$; JCPDS-ICDD card 04-0784), diagnostic of a well
Table 1 Gold loading, specific surface area (SSA), mean Au particle size from STEM analysis $(d), \mathrm{H}_{2}$ consumption during TPR, $\mathrm{H}_{2}$ and $\mathrm{O}_{2}$ uptake and support standard redox potential $\left(E_{\text {redox }}\right)$ for the supported Au catalysts

\begin{tabular}{llll}
\hline Catalyst & $\mathrm{Au} / \mathrm{TiO}_{2}$ & $\mathrm{Au} / \mathrm{CeO}_{2}$ & $\mathrm{Au} / \mathrm{Al}_{2} \mathrm{O}_{3}{ }^{\mathrm{a}}$ \\
\hline Au loading (mol\%) & 0.8 & 0.7 & 0.6 \\
$\mathrm{SSA}\left(\mathrm{m}^{2} \mathrm{~g}^{-1}\right)$ & 52 & 64 & 166 \\
$d(\mathrm{~nm})$ & 3.2 & 2.8 & 4.3 \\
$\mathrm{TPR} \mathrm{H}_{2}$ consumption $\left(\mu \mathrm{mol} \mathrm{g}^{-1}\right)$ & $174^{\mathrm{b}} / 147^{\mathrm{c}}$ & $495^{\mathrm{b}} / 61^{\mathrm{c}}$ & $87^{\mathrm{b}} / 84^{\mathrm{c}}$ \\
$\mathrm{H}_{2}$ chemisorption $\left(\mu \mathrm{mol} \mathrm{g}_{\mathrm{Au}}{ }^{-1}\right)^{\mathrm{d}}$ & 146 & 87 & 318 \\
$E_{\text {redox }}(\mathrm{V})^{\mathrm{e}}$ & -0.6 & 1.6 & -1.7 \\
$\mathrm{O}_{2}$ chemisorption $\left(\mu \mathrm{mol} \mathrm{g}^{-1}\right)^{\mathrm{d}}$ & 8 & 90 & 1 \\
\hline
\end{tabular}

${ }^{\text {a } D a t a ~ f r o m ~[22] ~}$

${ }^{\mathrm{b}}$ Experimental measurements

${ }^{\mathrm{c}} \mathrm{H}_{2}$ required for $\mathrm{Au}^{3+} \rightarrow \mathrm{Au}^{0}$

${ }^{\mathrm{d}}$ Measured at $413 \mathrm{~K}$

eTaken from [30]

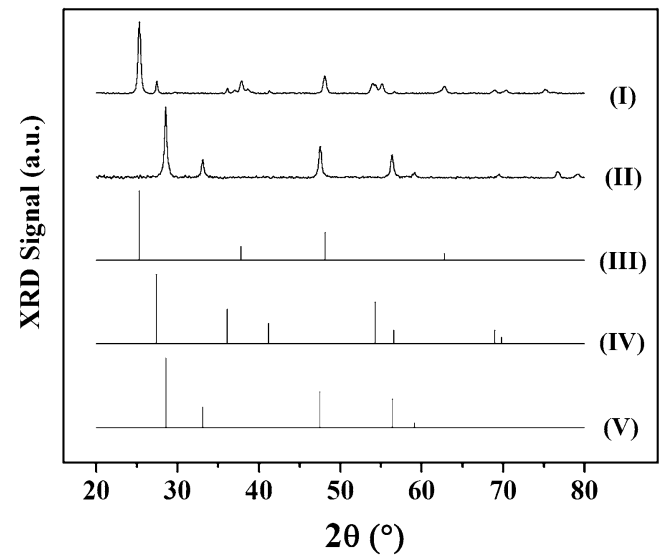

Fig. $1 \mathrm{XRD}$ patterns for $(I) \mathrm{Au} / \mathrm{TiO}_{2}$ and $(I I) \mathrm{Au} / \mathrm{CeO}_{2}$ with JCPDSICDD reference diffractograms for (III) anatase- $\mathrm{TiO}_{2}$ (21-1272), (IV) rutile- $\mathrm{TiO}_{2}(21-1276)$ and $(V) \mathrm{CeO}_{2}(43-1002)$

dispersed $(<5 \mathrm{~nm})$ metal phase [24]. This was confirmed by STEM analysis (Fig. 2) where both samples exhibited quasispherical Au nanoparticles (IA, IB) with similar size range (1-6 nm) and mean [(II); Table 1]. The TPR profile of Au/ $\mathrm{TiO}_{2}$ (Fig. 2IIIA) shows a single peak $\left(T_{\max }=376 \mathrm{~K}\right)$ with an associated $\mathrm{H}_{2}$ consumption that exceeded the amount required for the formation of $\mathrm{Au}^{0}$ (Table 1) but far lower than that $\left(6200 \mu \mathrm{mol} \mathrm{g}^{-1}\right)$ required for $\mathrm{Ti}^{4+} \rightarrow \mathrm{Ti}^{3+}$. This suggests a partial reduction of the support, notably at the Au-support interface [28]. Reduction of $\mathrm{Au} / \mathrm{CeO}_{2}$ (Fig. 2IIIB) exhibited $\mathrm{H}_{2}$ consumption at higher $T_{\max }(418 \mathrm{~K})$. Liu and Yang [29] reported a dependency of $\mathrm{Au}^{3+}$ reducibility on support redox properties where weaker interactions with $\mathrm{TiO}_{2}$ compared with $\mathrm{CeO}_{2}$ rendered the $\mathrm{Au}^{3+}$ component more susceptible to reduction. In the TPR of $\mathrm{Au} / \mathrm{CeO}_{2}, \mathrm{H}_{2}$ consumed was 
Fig. 2 (I) Representative STEM images with (II) associated Au particle size distribution histograms and (III) temperature programmed reduction (TPR) profiles for $\mathbf{A}$ $\mathrm{Au} / \mathrm{TiO}_{2}$ (solid bars) and $\mathbf{B ~ A u} /$ $\mathrm{CeO}_{2}$ (hatched bars)

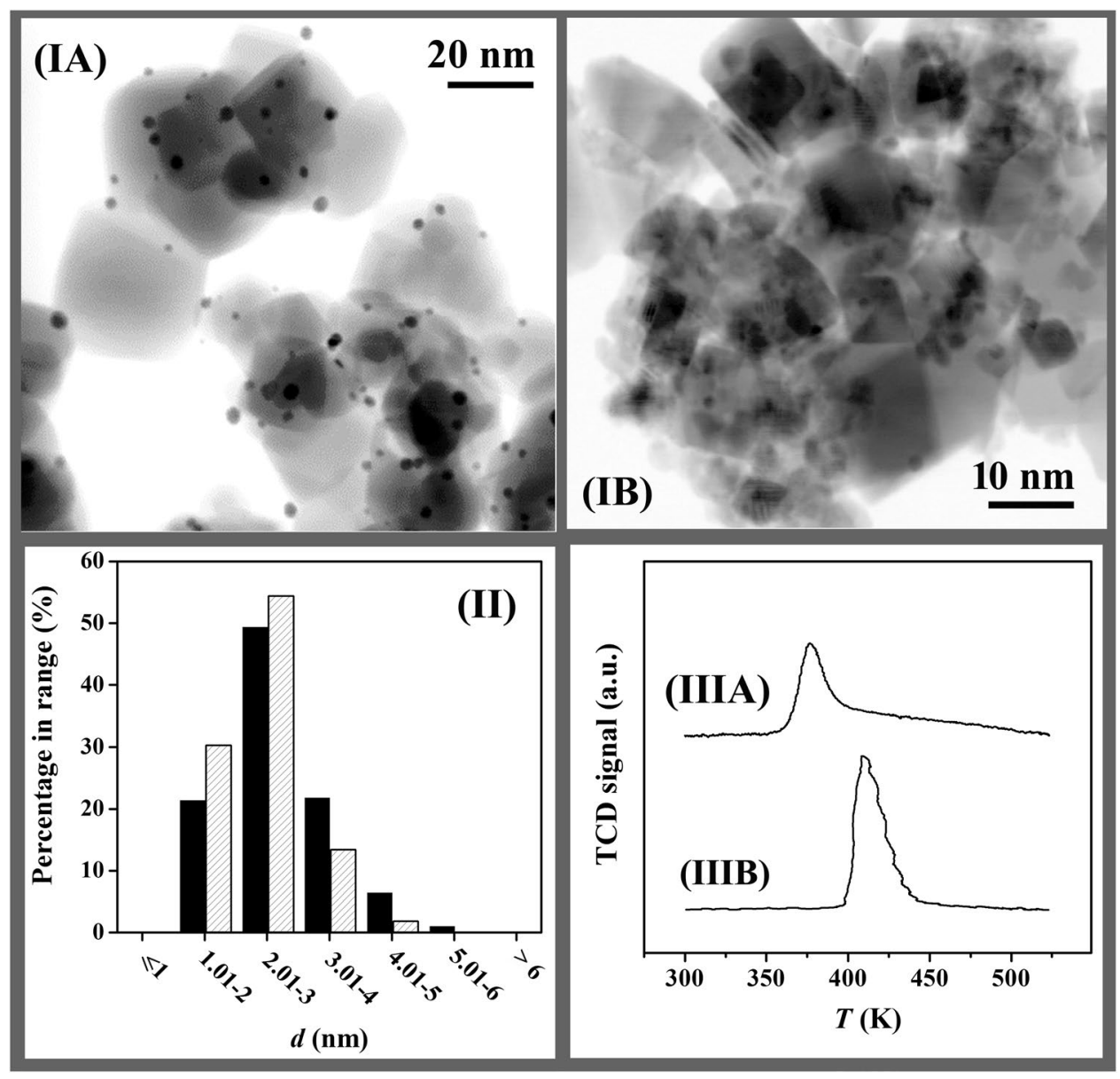

greater than the requirements for $\mathrm{Au}$ precursor reduction but considerably less than bulk $\mathrm{Ce}^{4+} \rightarrow \mathrm{Ce}^{3+}$ transformation $\left(2900 \mu \mathrm{mol} \mathrm{g}{ }^{-1}\right)$. There were no signals due to $\mathrm{Ce}_{2} \mathrm{O}_{3}$ (main peak $2 \theta=29.5^{\circ}$; JCPDS-ICDD card 23-1048) in the XRD pattern. Increased $\mathrm{H}_{2}$ uptake during activation of $\mathrm{Au} /$ $\mathrm{CeO}_{2}$ relative to $\mathrm{Au} / \mathrm{TiO}_{2}$ suggests a greater degree of support reduction. This agrees with the higher redox potential [30] of $\mathrm{CeO}_{2}\left(E_{\text {redox }}\right.$, Table 1$)$. In contrast, TPR analysis of benchmark $\mathrm{Al}_{2} \mathrm{O}_{3}$ (with the lowest $E_{\text {redox }}$ ) supported $\mathrm{Au}$ ( $d=4.3 \mathrm{~nm}$ ) generated an equivalent $\mathrm{H}_{2}$ consumption to the theoretical value for $\mathrm{Au}^{3+} \rightarrow \mathrm{Au}^{0}$, confirming support nonreducibility (Table 1 ).

The number of surface oxygen vacancies can be quantified by oxygen titration [23, 31]. Oxygen chemisorption post-TPR was employed to determine the extent of support reduction; the values are given in Table 1. Decreasing $\mathrm{O}_{2}$ uptake $\left(\mathrm{Au} / \mathrm{CeO}_{2}>\mathrm{Au} / \mathrm{TiO}_{2}>\mathrm{Au} / \mathrm{Al}_{2} \mathrm{O}_{3}\right)$ matched the sequence of decreasing support redox potential and $\mathrm{H}_{2}$ consumption during TPR. Oxygen vacancy formation in $\mathrm{TiO}_{2}$ has been established by in situ EPR following reduction (in $\mathrm{H}_{2}$ ) over 573-1073 K [32]. Boccuzzi et al. [33] using FTIR spectroscopy demonstrated $\mathrm{H}_{2}$ dissociation on $\mathrm{Au}$ sites supported on $\mathrm{TiO}_{2}$ (reduced at $523 \mathrm{~K}$ ) with spillover that resulted in surface reduction. It has been established (by DFT calculation and STM) that bare ceria surfaces can be reduced $\left(\mathrm{Ce}^{4+} \rightarrow \mathrm{Ce}^{3+}\right)$ to generate oxygen defects postactivation in $\mathrm{H}_{2}$ at 400-900 K [34, 35]. Addition of $\mathrm{Au}$ to ceria facilitates support reduction $(273-573 \mathrm{~K})$ during TPR [36]. The performance of supported Au catalysts in hydrogenation is determined by the capacity for $\mathrm{H}_{2}$ adsorption/dissociation [24]. Hydrogen chemisorption (at $413 \mathrm{~K}$, Table 1) on $\mathrm{Au} / \mathrm{TiO}_{2}$ was measurably higher than $\mathrm{Au} / \mathrm{CeO}_{2}$. Gold particle size and support interactions impact on $\mathrm{H}_{2}$ adsorption [37-39]. Corner and edge sites associated with smaller Au particles $(<10 \mathrm{~nm})$ have been identified as active for $\mathrm{H}_{2}$ dissociation [37]. Mean Au size is close for the three catalysts (Table 1). The order of decreasing $\mathrm{H}_{2}$ uptake (Au/ $\mathrm{Al}_{2} \mathrm{O}_{3}>\mathrm{Au} / \mathrm{TiO}_{2}>\mathrm{Au} / \mathrm{CeO}_{2}$ ) matches that of increasing $\mathrm{O}_{2}$ chemisorption (Table 1). Lower uptake on $\mathrm{Au} / \mathrm{TiO}_{2}$ and $\mathrm{Au} /$ $\mathrm{CeO}_{2}$ can be linked to metal encapsulation due to surface Au diffusion into the bulk $(573-673 \mathrm{~K})$ that is facilitated by oxygen vacancies on reducible oxides [40, 41], an effect more pronounced for $\mathrm{Au} / \mathrm{CeO}_{2}$ with higher vacancy density.

The characterisation results demonstrate the generation of nano-scale $\mathrm{Au}$ particles on $\mathrm{TiO}_{2}$ and $\mathrm{CeO}_{2}$ with a greater density of surface oxygen vacancies and lower $\mathrm{H}_{2}$ uptake on 
$\mathrm{Au} / \mathrm{CeO}_{2}$. Gold on non-reducible $\mathrm{Al}_{2} \mathrm{O}_{3}$ with similar metal size is a suitable candidate to evaluate the effect of oxygen vacancies on furfural hydrogenation over supported $\mathrm{Au}$.

\subsection{Catalytic Response}

A search through the literature did not produce any reported application of $\mathrm{TiO}_{2}$ or $\mathrm{CeO}_{2}$ supported Au catalysts in furfural hydrogenation. We can flag the work of Ohyama et al. [42] on high pressure (38 atm) liquid phase hydrogenation of 2-hydroxylmethyl-5-furfural where reaction over $\mathrm{Au} / \mathrm{TiO}_{2}$ resulted in furan ring opening and $\mathrm{Au} / \mathrm{CeO}_{2}$ promoted carbonyl group reduction at a (tenfold) lower activity. No explanation was given for the observed differences in selectivity or activity. Gas phase furfural hydrogenation at $413 \mathrm{~K}$ over $\mathrm{Au} / \mathrm{TiO}_{2}$ generated the target furfuryl alcohol as sole product (Fig. 3I). Reaction over $\mathrm{Au} / \mathrm{Al}_{2} \mathrm{O}_{3}$ delivered an appreciably higher selective turnover frequency (TOF) and $\mathrm{Au} /$ $\mathrm{CeO}_{2}$ was inactive (Fig. 3II). This activity response can be linked to differences in $\mathrm{H}_{2}$ chemisorption capacity (Table 1, in the order $\mathrm{Au} / \mathrm{Al}_{2} \mathrm{O}_{3}>\mathrm{Au} / \mathrm{TiO}_{2}>\mathrm{Au} / \mathrm{CeO}_{2}$ ) under reaction conditions. Zanella et al. [43] identified $\mathrm{H}_{2}$ dissociation as rate-determining in the chemoselective hydrogenation of aldehydes over supported Au. In this study, the TOF normalised with respect to $\mathrm{H}_{2}$ chemisorption capacity was lower for $\mathrm{Au}$ on reducible supports (notably $\mathrm{Au} / \mathrm{CeO}_{2}$ ) relative to $\mathrm{Au} /$ $\mathrm{Al}_{2} \mathrm{O}_{3}$. This suggests a contribution due to furfural adsorption at surface oxygen vacancies. These vacancies can act as sites for strong binding of oxygenated reactants $[34,44]$. The higher density of oxygen vacancies on $\mathrm{Au} / \mathrm{CeO}_{2}$ (Table 1) can act to stabilise surface adsorbed furfural, resulting in lower reaction rates. The action of oxygen vacancies to inhibit $-\mathrm{C}=\mathrm{O}$ reduction is in line with the lower activity recorded for cinnamaldehyde hydrogenation (to cinnamyl alcohol) over $\mathrm{Au} / \mathrm{CeO}_{2}$ relative to $\mathrm{Au} / \mathrm{MgO}-\mathrm{Al}_{2} \mathrm{O}_{3}$ reported by Tian et al. [19] though this possibility was not proposed by the authors. An increase in temperature ( $\geq 473 \mathrm{~K}$ ) (i) elevated $T O F$ where $\mathrm{Au} / \mathrm{CeO}_{2}$ consistently delivered lower rates (Fig. 3II) and (ii) resulted in a switch in selectivity from furfuryl alcohol to 2-methylfuran. Reaction over $\mathrm{Au} /$ $\mathrm{TiO}_{2}$ and $\mathrm{Au} / \mathrm{Al}_{2} \mathrm{O}_{3}$ at $523 \mathrm{~K}$ generated 2-methylfuran as principal product $(S>91 \%)$. In the case of $\mathrm{Au} / \mathrm{CeO}_{2}$, a higher reaction temperature $(473 \mathrm{~K})$ resulted in the selective transformation of furfural to furfuryl alcohol while a further increase (to $523 \mathrm{~K}$ ) generated 2-methylfuran as by-product. These results suggest that elevated temperatures favour activation of $-\mathrm{C}=\mathrm{O}$ for hydrogenolytic cleavage, which finds agreement in results reported for $\mathrm{Cu} / \mathrm{MgO}$ [45].

Ceria supported $\mathrm{Au}$ with a greater oxygen vacancy density exhibited a distinct catalytic response compared with $\mathrm{Au} / \mathrm{TiO}_{2}$ and $\mathrm{Au} / \mathrm{Al}_{2} \mathrm{O}_{3}$. We propose a reaction mechanism that involves direct participation of surface vacancies where the carbonyl group of furfural can be "anchored" to a vacancy $\left(\mathrm{Ce}^{3+}\right)$ site (see Fig. $4 \mathrm{I}$ ), forming a covalent $\mathrm{Ce}-\mathrm{O}$ bond with a high energy of interaction [46] that stabilises the surface reactant and lowers reactivity. The (stabilised) carbonyl group can be activated for reaction at higher temperature $(523 \mathrm{~K})$ where hydrogenolysis to 2 -methylfuran results from hydrogen scission of $-\mathrm{C}=\mathrm{O}$. The surface $\mathrm{Ce}^{3+}$ sites are oxidised by the abstracted oxygen from the carbonyl group. Oxygen vacancies can be regenerated by $\mathrm{H}_{2}$ dissociated on Au sites that spills over to the support, resulting in a continuous creation/ consumption/regeneration of these vacancies. Another possible adsorption mode is through the furan ring oxygen that interacts with the electron-rich vacancy site [47] (Fig. 4II). The energy barrier for reaction is lower relative to the covalent $-\mathrm{C}=\mathrm{O}$ " anchoring" at vacancies. In this case, the carbonyl group is attacked by reactive hydrogen to form the target furfuryl alcohol with subsequent desorption. Oxygen defects are also present on $\mathrm{Au} / \mathrm{TiO}_{2}$ but at a lower density with a consequent higher conversion to furfuryl alcohol at lower reaction temperature. Interaction of $-\mathrm{C}=\mathrm{O}$ with Lewis acid sites $\left(\mathrm{Al}^{3+}\right)$ on non-reducible $\mathrm{Al}_{2} \mathrm{O}_{3}$ facilitates $-\mathrm{C}=\mathrm{O}$ activation [27] and results in greater reactivity and higher $T O F$.
Fig. 3 Variation of I furfuryl alcohol selectivity

$\left(S_{\text {Furfuryl alcohol }}\right)$ at an equivalent fractional furfural conversion and II turnover frequency (TOF) with temperature for reaction over $\mathrm{Au} / \mathrm{TiO}_{2}$ (solid bars), $\mathrm{Au} / \mathrm{CeO}_{2}$ (hatched bars) and $\mathrm{Au} / \mathrm{Al}_{2} \mathrm{O}_{3}$ (grey bars). Reaction conditions: $P=1 \mathrm{~atm}$; $T=413-523 \mathrm{~K}$

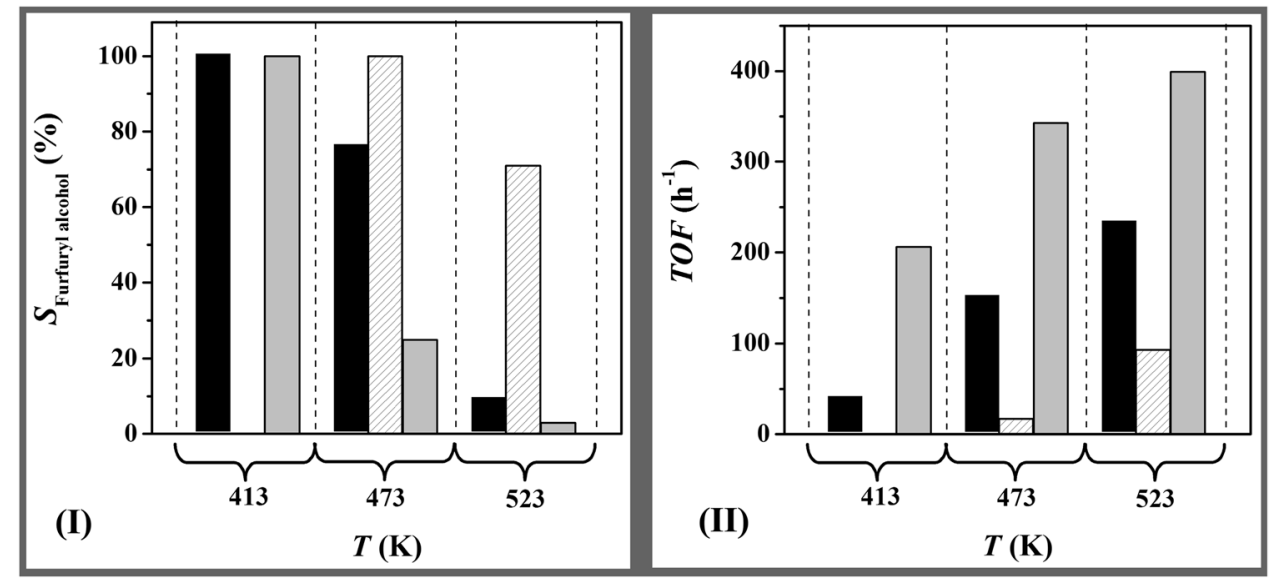




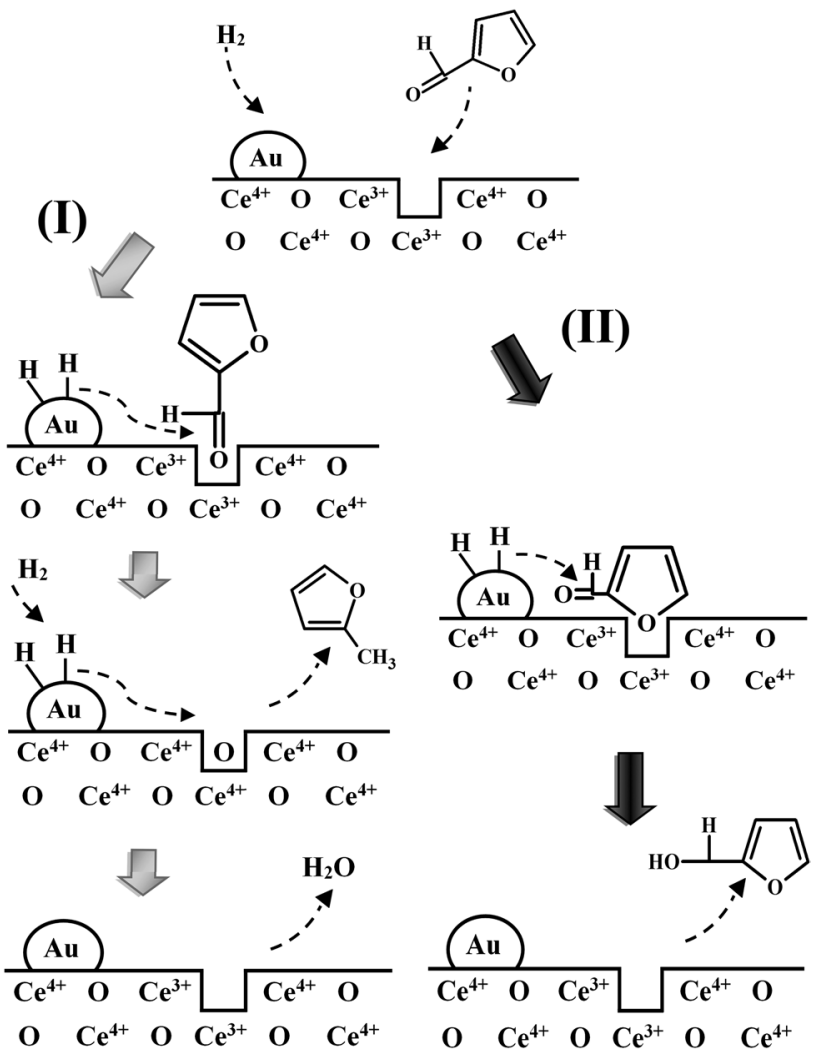

Fig. 4 Proposed surface furfural adsorption/activation and reaction for $\mathrm{Au}$ on reducible supports $\left(\mathrm{CeO}_{2}\right)$ at oxygen vacancies via $(I)$ the carbonyl group (grey arrows) or (II) furan ring (black arrows)

\section{Conclusion}

We have established structure sensitivity in the gas phase hydrogenation of furfural over $(0.7-0.8 \mathrm{~mol} \%) \mathrm{Au} / \mathrm{TiO}_{2}$ and $\mathrm{Au} / \mathrm{CeO}_{2}$ (mean Au particle size $=2.8-3.2 \mathrm{~nm}$ ). A surface reaction mechanism is proposed to explain the role of surface oxygen vacancies in determining hydrogenation activity and selectivity. Reaction over $\mathrm{Au} / \mathrm{CeO}_{2}$ delivered lower furfural TOF, which can be linked to inhibited $\mathrm{H}_{2}$ chemisorption capacity. The greater oxygen vacancy density on $\mathrm{CeO}_{2}$ (with higher redox potential) post-TPR served to stabilise the $-\mathrm{C}=\mathrm{O}$ function and lower reactivity. Full selectivity to the alcohol was achieved over $\mathrm{Au} / \mathrm{TiO}_{2}$ (at $413 \mathrm{~K}$ ) and $\mathrm{Au} / \mathrm{CeO}_{2}$ (at $473 \mathrm{~K}$ ) where hydrogenolysis to 2-methylfuran was promoted at $523 \mathrm{~K}$. Reaction over $\mathrm{Au}$ on non-reducible $\mathrm{Al}_{2} \mathrm{O}_{3}$ delivered higher furfural TOF (at $413 \mathrm{~K}$ ) to furfuryl alcohol with 2-methylfuran formation at $T \geq 473 \mathrm{~K}$.

Acknowledgements We thank Dr. X. Wang for his contribution to this study. The work was supported in part by the Engineering \& Physical Sciences Research Council (Grant EP/M029476/1). Financial support to Dr. M. Li through the Overseas Research Students Award Scheme (ORSAS) is also acknowledged.
Open Access This article is distributed under the terms of the Creative Commons Attribution 4.0 International License (http://creativecommons.org/licenses/by/4.0/), which permits unrestricted use, distribution, and reproduction in any medium, provided you give appropriate credit to the original author(s) and the source, provide a link to the Creative Commons license, and indicate if changes were made.

\section{References}

1. Setvín M, Aschauer U, Scheiber P, Li Y-F, Hou W, Schmid M, Selloni A, Diebold U (2013) Science 341:988

2. Su J, Zou X, Chen J-S (2014) RSC Adv 4:13979

3. Ganduglia-Pirovano MV, Hofmann A, Sauer J (2007) Surf Sci Rep 62:219

4. Mullins DR (2015) Surf Sci Rep 70:42

5. Pan X, Yang M-Q, Fu X, Zhang N, Xu Y-J (2013) Nanoscale $5: 3601$

6. Weaver JF, Zhang F, Pan L, Li T, Asthagiri A (2015) Acc Chem Res 48:1515

7. Vecchietti J, Bonivardi A, Xu W, Stacchiola D, Delgado JJ, Calatayud M, Collins SE (2014) ACS Catal 4:2088

8. Oemar U, Ang ML, Chin YC, Hidajat K, Kawi S (2015) Catal Sci Technol 5:3585

9. Yu Y-Y, Gong X-Q (2015) ACS Catal 5:2042

10. Thibodeau TJ, Canney AS, DeSisto WJ, Wheeler MC, Amar FG, Frederick BG (2010) Appl Catal A 388:86

11. Chang S, Li M, Hua Q, Zhang L, Ma Y, Ye B, Huang W (2012) J Catal 293:195

12. Ta N, Liu J, Chenna S, Crozier PA, Li Y, Chen A, Shen W (2012) J Am Chem Soc 134:20585

13. Maeda Y, Iizuka Y, Kohyama M (2013) J Am Chem Soc 135:906

14. Ge J, Zeng Z, Liao F, Zheng W, Hong X, Tsang SCE (2013) Green Chem 15:2064

15. Wang D, Astruc D (2015) Chem Rev 115:6621

16. Sepúlveda-Escribano A, Coloma F, Rodríguez-Reinoso F (1998) J Catal 178:649

17. Milone C, Ingoglia R, Schipilliti L, Crisafulli C, Neri G, Galvagno S (2005) J Catal 236:80

18. Bachiller-Baeza B, Rodríguez-Ramos I, Guerrero-Ruiz A (2001) Appl Catal A 205:227

19. Tian Z, Xiang X, Xie L, Li F (2013) Ind Eng Chem Res 52:288

20. Wang X, Perret N, Delgado JJ, Blanco G, Chen X, Olmos CM, Bernal S, Keane MA (2013) J Phys Chem C 117:994

21. Wang X, Perret N, Keane MA (2012) Chem Eng J 210:103

22. Li M, Hao Y, Cárdenas-Lizana F, Keane MA (2015) Catal Commun 69:119

23. Salasc S, Perrichon V, Primet M, Mouaddib-Moral N (2002) J Catal 206:82

24. Bond GC, Louis C, Thompson DT (2006) Catalysis by gold. Imperial College Press, London

25. Li M, Wang X, Perret N, Keane MA (2014) Catal Commun 46:187

26. Jovic V, Chen W-T, Sun-Waterhouse D, Blackford MG, Idriss H, Waterhouse GIN (2013) J Catal 305:307

27. Perret N, Wang X, Onfroy T, Calers C, Keane MA (2014) J Catal 309:333

28. Ousmane M, Liotta LF, Carlo GD, Pantaleo G, Venezia AM, Deganello G, Retailleau L, Boreave A, Giroir-Fendler A (2011) Appl Catal B 101:629

29. Liu SY, Yang SM (2008) Appl Catal A 334:92

30. Haffad D, Kameswari U, Bettahar MM, Chambellan A, Lavalley JC (1997) J Catal 172:85 
31. Salasc S, Perrichon V, Primet M, Chevrier M, Mouaddib-Moral N (2000) J Catal 189:401

32. Liu H, Ma HT, Li XZ, Li WZ, Wu M, Bao XH (2003) Chemosphere 50:39

33. Boccuzzi F, Chiorino A, Manzoli M, Andreeva D, Tabakova T (1999) J Catal 188:176

34. Campbell CT, Peden CHF (2005) Science 309:713

35. Popa C, Ganduglia-Pirovano MV, Sauer J (2011) J Phys Chem C 115:7399

36. Fu Q, Saltsburg H, Flytzani-Stephanopoulos M (2003) Science 301:935

37. Manzoli M, Chiorino A, Vindigni F, Boccuzzi F (2012) Catal Today 181:62

38. Nakamura I, Mantoku H, Furukawa T, Fujitani T (2011) J Phys Chem C 115:16074
39. Nakamura I, Mantoku H, Furukawa T, Takahashi A, Fujitani T (2012) Surf Sci 606:1581

40. Akita T, Okumura M, Tanaka K, Kohyama M, Haruta M (2005) J Mater Sci 40:3101

41. Campo B, Volpe M, Ivanova S, Touroude R (2006) J Catal 242:162

42. Ohyama J, Esaki A, Yamamoto Y, Arai S, Satsuma A (2013) RSC Adv 3:1033

43. Zanella R, Louis C, Giorgio S, Touroude R (2004) J Catal 223:328

44. Paier J, Penschke C, Sauer J (2013) Chem Rev 113:3949

45. Nagaraja BM, Padmasri AH, Raju BD, Rao KSR (2007) J Mol Catal A 265:90

46. Kennedy G, Baker LR, Somorjai GA (2014) Angew Chem Int Ed 53:3405

47. Badawi M, Cristol S, Paul J-F, Payen E (2009) C R Chimie 12:754 